\title{
Association of change on insulin-like growth factor (IGF)-i and IGF-binding protein 3 with genetic markers after a month of growth hormone $(\mathrm{GH})$ therapy on Chinese children born with GH deficiency
}

\author{
Wei Wang ${ }^{1 *}$, Shuixian Shen ${ }^{2}$, Xiaoping Luo ${ }^{3}$, Chunxiu Gong ${ }^{4}$, Xuefan Gu${ }^{5}$, Yun Li ${ }^{6}$, Minlian Minlian ${ }^{7}$, Minlian Jin $^{8}$, \\ Bin $\mathrm{Wu}^{9}$
}

From 7th APPES Biennial Scientific Meeting

Nusa Dua, Bali. 14-17 November 2012

\section{Aims}

To identify genetic markers associated with changes in IGF-I and IGFBP3 standard deviation score (SDS) after 1 month of $\mathrm{r}$-hGH treatment in Chinese GHD children either born Appropriate for Gestational Age (AGA) or Small for Gestational Age (SGA).

\section{Methods}

This phase IV open-label interventional study was performed on samples from 205 GHD children (175 subjects born AGA and 30 subjects SGA) of Chinese Han origin, recruited at 8 centers. All the subjects were given $\mathrm{r}$-hGH for 4 weeks $(0.033 \mathrm{mg} / \mathrm{kg} / \mathrm{d}) .1536$ SNPs were selected from 100 Candidate Genes involved in the GHIGFI axes, growth plate and other short stature-related diseases. We genotyped Single nucleotide polymorphism (SNP) using Illumina GoldenGate ${ }^{\mathrm{TM}}$ Assays. Linear regression was used to identify single SNPs significantly associated with changes, from baseline to week 4, in serum IGF-I SDS and IGFBP3 SDS. Gestational age (GA) was also included in the model. The significance threshold was set as a corrected $\mathrm{P}$-value $<0.05$. Multiple linear regressions with interaction effect were used to identify significantly associated genes with changes, from baseline to week 4, in serum IGF-I SDS and IGFBP3 SDS. The significance threshold was set as a corrected P-value $<0.1$.

\section{Results}

(1) 6/19 SNPs which correspond to 4/17 genes were significantly associated with IGF-I SDS change/IGFBP3 SDS change separately from baseline to Week 4 in all samples (AGA+SGA) with a corrected $\mathrm{P}$-value $<0.05$. Among them, 3/10 SNPs showed significant interaction effects, suggesting that the pattern of SNPs associated with IGF-I SDS change/IGFBP3 SDS change was different between two groups.

(2) 14/14 genes which significantly associated with IGF-I SDS change/IGFBP3 SDS change at Week 4 were identified in all samples (AGA+SGA). Among them, 6/ 12 genes showed significant interaction effects, suggesting that IGF-I SDS change/IGFBP3 SDS change have different effect on these genes expression between two groups. We also found that 5 genes in common associated with both IGF-I SDS change and IGFBP-3 SDS change.

\section{Conclusions}

The results of our study demonstrate the genetic association between polymorphic variations of some candidate genes and serum IGF-I and IGFBP3 SDS changes after $\mathrm{r}$-hGH therapy in children with GHD born SGA and AGA, suggesting that these genetic markers could be used into clinical practice in order to optimize efficacy, safety and cost of r-hGH therapy. 


\section{Authors' details}

${ }^{1}$ Ruijin Hospital, Jiaotong University School Of Medicine, Shanghai, China. ${ }^{2}$ Children's Hospital of Fudan University, Shanghai, China. ${ }^{3}$ Tongji Hospital Wuhan, China. ${ }^{4}$ Beijing Children's Hospital, Beijing, China. ${ }^{5}$ Xinhua Hospital, Shanghai, China. ${ }^{6}$ Children's Hospital, Zhejiang University, Hangzhou, China. ${ }^{7}$ First Affiliated Hospital, Sun Yat-sen University, Guangzhou, China. ${ }^{8}$ Union Hospital, Wuhan, China. ${ }^{9}$ Merck Serono China, Beijing, China.

Published: 3 October 2013

doi:10.1186/1687-9856-2013-S1-P62

Cite this article as: Wang et al: Association of change on insulin-like growth factor (IGF)-i and IGF-binding protein 3 with genetic markers after a month of growth hormone (GH) therapy on Chinese children born with GH deficiency. International Journal of Pediatric Endocrinology 2013 2013(Suppl 1):P62.

Submit your next manuscript to BioMed Central and take full advantage of:

- Convenient online submission

- Thorough peer review

- No space constraints or color figure charges

- Immediate publication on acceptance

- Inclusion in PubMed, CAS, Scopus and Google Scholar

- Research which is freely available for redistribution

Submit your manuscript at www.biomedcentral.com/submit 